\title{
Penerapan Model Pembelajaran Kooperatif Tipe STAD Untuk Meningkatkan Keaktifan Dan Hasil Belajar IPS Pada Siswa Kelas VB SDN 1 Kaliwuluh Semester I Tahun Pelajaran 2020/2021
}

\author{
Yunita A. Prabawati \\ SDN 01 Kaliwuluh \\ maliez453@gmail.com
}

\section{Article History}

received $3 / 12 / 2020$

\begin{abstract}
This study aims to increase activity and low social studies learning outcomes. The implementation of this Classroom Action Research was carried out in two cycles, with each cycle consisting of planning, implementing actions, observing, and reflecting. The subjects of this study were students of class VB SDN 01 Kaliwuluh which opened 21 students with the object of research on student activities and learning outcomes. From the results of data analysis it is known that in each cycle there is an increase in student activity and learning outcomes. In the condition, the percentage of student learning activities is only $22.66 \%$, while the learning outcomes are $63.64 \%$ below the KKM. In the first cycle, learning activities increased to $62.99 \%$ and learning outcomes reached $68.18 \%$. In the second cycle, student activity increased to $77.89 \%$ and learning outcomes reached $86.36 \%$. Based on Classroom Action Research, it can be said that the application of the STAD type cooperative learning model can increase the activeness and learning outcomes of social studies students in class V B SDN 01 Kaliwuluh in semester 1 of the 2020/2021 academic year.
\end{abstract}

Keywords: STAD, student activity, learning outcomes

\begin{abstract}
Abstrak
Penelitian ini bertujuan meningkatkan aktivitas dan rendahnya hasil belajar IPS. Pelaksanaan Penelitian Tindakan Kelas ini dilaksanakan dalam dua siklus, dengan setiap siklus terdiri dari perencanaan, pelaksanaan tindakan, observasi, dan refleksi. Subjek penelitian ini adalah siswa kelas VB SDN 01 Kaliwuluh yang berjumlah 21 siswa dengan objek penelitian aktivitas siswa dan hasil belajar. Dari hasil analisis data diketahui bahwa pada setiap siklusnya terjadi peningkatan aktivitas dan hasil belajar siswa. Pada kondisi awal persentase aktivitas belajar siswa hanya $22,66 \%$, sedangkan hasil belajar $63,64 \%$ di bawah KKM. Pada siklus I, aktivitas belajar meningkat menjadi $62,99 \%$ dan hasil belajar mencapai $68,18 \%$. Pada siklus II aktivitas siswa meningkat menjadi $77,89 \%$ dan hasil belajar mencapai $86,36 \%$. Berdasarkan hasil Penelitian Tindakan Kelas dapat disimpulkan bahwa penerapan model pembelajaran kooperatif tipe STAD dapat meningkatkan keaktifan dan hasil belajar IPS siswa kelas V B SDN 01 Kaliwuluh semester 1 tahun ajaran 2020/2021.
\end{abstract}

Kata kunci: STAD, keaktifan siswa, hasil belajar

Social, Humanities, and Education Studies (SHEs): Conference Series https://jurnal.uns.ac.id/shes

p-ISSN 2620-9284

e-ISSN 2620-9292 


\section{PENDAHULUAN}

Pendidikan merupakan salah satu hal yang sangat penting untuk membekali siswa menghadapi masa depan. Untuk itu proses pembelajaran yang bermakna sangat menentukan terwujudnya pendidikan yang berkulitas. Siswa perlu mendapatkan bimbingan, dorongan, dan peluang yang memadai untuk belajar dan mempelajari halhal yang diperlukan dalam kehidupannya.

Pendidikan merupakan suatu proses untuk membantu manusia dalam mengembangkan potensinya sehingga dapat menghadapi setiap perubahan yang terjadi. Melalui pendidikan, manusia dapat meningkatkan pengetahuan, kemampuan, dan kreativitas terhadap perkembangan ilmu pengetahuan dan teknologi. Selain itu, fungsi lain dari pendidikan adalah untuk mengurangi kebodohan, karena ilmu pengetahuan dan keterampilan yang diperoleh dapat menjadikan seseorang mampu mengatasi suatu problematika.

Ilmu Pengetahuan Sosial (IPS) merupakan salah satu mata pelajaran yang diberikan mulai dari sekolah dasar sampai ke perguruan tinggi, Sapriya berpendapat, "IPS mengkaji seperangkat peristiwa, fakta, konsep, dan generalisasi yang berkaitan dengan isu sosial,ada jenjang Sekolah Dasar mata pelajaran IPS memuat materi Geografi, Sejarah, Sosiologi, dan Ekonomi” (2009: 20).

Tujuan pembelajaran IPS pada jenjang sekolah dasar menurut Lasmawan (2010) adalah untuk mendidik dan memberi bekal kemampuan dasar pada siswa untuk mengembangkan diri sesuai dengan bakat, minat dan kemampuan, serta sebagai bekal bagi siswa untuk melanjutkan pendidikan ke jenjang yang lebih tinggi.

Melalui pembelajaran IPS dapat membina dan menyiapkan siswa sebagai warga negara yang baik dan memasyarakat diharapkan mampu mengantisipasi berbagai perubahan yang terjadi di masyarakat sehingga siswa mempunyai bekal pengetahuan dan keterampilan dalam menjalani kehidupan di masyarakat. Guru dituntut untuk mampu mengikuti dan mengantisipasi berbagai perubahan masyarakat tersebut, sehingga program pembelajaran yang dilakukannya dapat membantu siswa dalam mempersiapkan dirinya sebagai warga masyarakat dan warga negara untuk memecahkan berbagai persoalan yang dihadapi dalam kehidupannya sehari-hari.

Guru harus cermat dalam memilih model pembelajaran dan merancang proses pembelajaran, sehingga pembelajaran yang dilakukannya menjadi pembelajaran yang menarik bagi siswa. Dalam pembelajaran IPS seharusnya guru dapat menggunakan model pembelajaran yang inovatif sehingga dapat meningkatkan hasil belajar siswa dan siswapun dapat ikut aktif dalam proses pembelajarannya.

Pembelajaran IPS saat ini masih didominasi dengan metode pembelajaran yang berpusat pada guru (teacher center). Guru hanya menggunakan metode ceramah dan tanya jawab saat menjelaskan materi pelajaran tanpa memperhatikan keterlibatan siswa dalam pembelajaran. Guru berperan aktif dalam pembelajaran dan berperan sebagai sumber informasi sedangkan siswa hanya berperan pasif dalam pembelajaran dengan memperhatikan informasi yang disampaikan oleh guru. Kegiatan siswa dalam pembelajaran hanya duduk, mendengar, dan mencatat materi yang disampaikan guru kemudian menghafal materi tersebut. Oleh karena itu banyak siswa yang tidak menyukai pelajaran IPS karena dianggap sebagai pelajaran yang membosankan.

Proses pembelajaran IPS yang dilaksanakan pada kelas V SDN 01 Kaliwuluh guru masih menggunakan metode ceramah. Metode tersebut mengakibatkan siswa cenderung kurang aktif dan hanya duduk mendengarkan materi yang disampaikan oleh guru saja.

Hasil observasi kondisi awal keaktifan siswa, dari 7 indikator observasi. 1) Mencari informasi dan sumber belajar untuk pemecahan masalah 0 siswa (0\%). 2) Menulis penjelasan guru 8 siswa $(36,36 \%)$. 3) Kerjasama dengan teman 3 siswa $(27,27 \%)$. 4) Mengajukan pertanyaan pada guru 2 siswa (22,72\%). 5) Menjawab pertanyaan guru atau teman 3 siswa (13,63\%). 6) Menulis hasil laporan diskusi dengan 
bekerjasama dengan kelompok 3 siswa (13,63\%). 7) Melaporkan hasil diskusi secara lisan 2 siswa $(9,09 \%)$. Sedangkan dari daftar nilai bahwa kondisi awal menunjukkan 13 siswa $(63,63 \%)$ dari 21 siswa memperoleh nilai di bawah Kriteria Ketuntasan Minimal (KKM) yaitu 75 dan nilai siswa yang sudah mencapai KKM hanya terdapat 8 $(36,36 \%)$ siswa. Dari data tersebut diketahui bahwa keaktifan dan hasil belajar siswa dalam mata pelajaran IPS rendah.

Keaktifan belajar siswa dalam pelajaran IPS akan lebih meningkat jika menerapkan model pembelajaran kooperatif, karena dalam pembelajaran kooperatif siswa dituntuk untuk lebih aktif berdiskusi di dalam kelompoknya. Dengan model pembelajaran kooperatif siswa dilatih untuk bertanggungjawab terhadap kelompoknya dan juga dilatih untuk menghargai pendapat orang lain di dalam kelompoknya tersebut.

Pembelajaran kooperatif adalah suatu model pembelajaran yang saat ini banyak digunakan untuk mewujudkan kegiatan belajar mengajar yang berpusat pada siswa (student centered), terutama untuk mengatasi permasalahan yang ditemukan guru dalam mengaktifkan siswa, yang tidak dapat bekerja sama dengan orang lain, siswa yang agresif dan tidak peduli pada orang lain.

Dalam pembelajaran kooperatif dikenal berbagai tipe salah satunya adalah pembelajaran kooperatif tipe Student Team Achievement Division (STAD). Model pembelajaran kooperatif tipe STAD dapat meningkatkan kerja kelompok yang efektif untuk mencapai tujuan pembelajaran di kelas. Dalam model pembelajaran kooperatif tipe STAD siswa dibagi menjadi kelompok heterogen baik dari segi etnis, jenis kelamin, dan kemampuan yang berbeda. Hal ini diharapkan agar siswa lebih aktif dalam mengikuti pembelajaran dan dapat menghargai pendapat dari teman satu kelompoknya. Dengan bekerjasama dalam kelompok siswa yang memiliki hasil belajar rendah dapat meningkatkan hasil belajarnya dengan bantuan teman satu kelompoknya, karena dalam model pembelajaran ini siswa akan saling membantu apabila ada teman anggota kelompoknya ada yang mengalami kesulitan dalam memahami materi pelajaran.

Berdasarkan masalah yang telah ditemukan di kelas VB SDN 01 Kaliwuluh, maka untuk mengatasi kendala yang dihadapi pada pembelajaran IPS yaitu dengan menerapkan model pembelajaran kooperatif tipe STAD. Dengan menggunakan model pembelajaran ini diharapkan dapat meningkatkan keaktifan dan hasil belajar siswa pada mata pelajaran IPS.

Berdasarkan latar belakang di atas, penulis akan melakukan penelitian tindakan kelas dengan mengangkat judul "Penerapan Model Pembelajaran Kooperatif Tipe STAD Untuk Meningkatkan Keaktifan Dan Hasil Belajar IPS Pada Siswa Kelas VB SDN 1 Kaliwuluh Semester I Tahun Pelajaran 2020/2021"

\section{METODE}

Penelitian ini dilaksanakan di kelas VB SDN 01 Kaliwuluh yang beralamat di Dusun Teken Desa Kaliwuluh Kecamatan Kebakkramat Kabupaten Karanganyar

Penelitian ini berbentuk penelitian tindakan kelas yang mekanisme kerjanya diwujudkan dalam bentuk siklus. Dalam penelitian tindakan kelas ini direncanakan 2 siklus dan setiap siklus terdiri dari 2 pertemuan. Di mana setiap pertemuan terdiri dari 4 tahap yaitu, (1) perencanaan (planning), (2) tindakan (acting), (3) pengamatan (observing), (4) refleksi (reflecting). Siklus ini akan dijabarkan dalam rencana pelaksanaan pembelajaran (RPP), di mana setiap pertemuan dalam setiap siklus ini waktunya 2 x 35 menit.

Teknik pengumpulan data yang digunakan dalam memperolah data keaktifan dan hasil belajar antara lain :

1. Observasi 
Observasi dilaksanakan untuk mengetahui keaktifan siswa selama proses pembelajaran berlangsung dalam penerapan model pembelajaran kooperatif tipe STAD.

2. Tes

Tes digunakan untuk mengukur hasil belajar siswa. Tes dilaksanakan pada akhir pembelajaran dalam setiap siklus. Tes yang digunakan dalam penelitian ini adalah pilihan ganda dan isian. Setiap siswa dalam mengerjakan soal tes melalui google form.

3. Dokumentasi

Dokumentasi pada penelitian ini digunakan sebagai laporan kegiatan selama pembelajaran berupa keaktifan dan hasil belajar siswa.

\section{HASIL DAN PEMBAHASAN}

Sebelum melaksanakan tindakan, peneliti mengadakan observasi untuk mengetahui data awal mengenai keaktifan dan hasil belajar siswa. Berdasarkan observasi dengan mengisi lembar keaktifan diperoleh data sebagai berikut:

Tabel 1 Presentase Keaktifan Belajar IPS Kondisi Awal

\begin{tabular}{clcc}
\hline No & \multicolumn{1}{c}{ Indikator } & Jumlah & Presentase \\
\hline 1 & Mencari informasi dan sumber belajar & 1 & $4,55 \%$ \\
2 & Menulis penjelasan guru & 10 & $45,45 \%$ \\
3 & Kerjasama dengan teman & 6 & $27,27 \%$ \\
4 & Mengajukan pertanyaan pada guru & 2 & $22,72 \%$ \\
5 & Menjawab pertanyaan guru atau teman & 6 & $27,27 \%$ \\
6 & Menulis hasil laporan diskusi dengan & 4 & $18,18 \%$ \\
7 & bekerjasama dengan kelompok & 4 & $18,18 \%$ \\
& Melaporkan hasil diskusi & 33 & $158,62 \%$ \\
& Jumlah & $4,71 \%$ & $22,66 \%$ \\
\hline
\end{tabular}

Tabel 2 Presentase Hasil Belajar IPS Kondisi Awal

\begin{tabular}{llcc}
\hline \multirow{2}{*}{ No } & & \multirow{2}{*}{ Ketuntasan } & \multicolumn{2}{c}{ Jumlah Siswa } \\
& & Jumlah & Presentase \\
\hline 1 & Tuntas & 8 & $36,36 \%$ \\
2 & Tidak Tuntas & 13 & $63,64 \%$ \\
& Jumlah & 21 & $100 \%$ \\
\hline
\end{tabular}

Tabel 1 dan tabel 2 menunjukkan presentase keaktifan dan hasil belajar IPS siswa kelas VB SDN 01 Kaliwuluh pada kondisi awal. Sebelum tindakan, dari 7 indikator keaktifan belajar IPS siswa menunjukan bahwa rata-rata keaktifan belajar IPS peserta didik hanya $4,71 \%$. Sedangkan peserta hasil belajar IPS pada kondisi awal adalah dari 21 peserta didik dengan KKM 75 hanya ada 8 peserta didik yang tuntas atau memenuhi KKM dan 13 peserta didik masih di bawah KKM. 
SHEs: Conference Series 3 (4) (2020) 528- 535

Tabel 3 Perbandingan Keaktifan Belajar IPS pada Siklus I

\begin{tabular}{|c|c|c|c|}
\hline No & Indikator & Jumlah & Presentase \\
\hline 1 & Mencari informasi dan sumber belajar & 15 & $71,42 \%$ \\
\hline 2 & Menulis penjelasan guru & 16 & $76,19 \%$ \\
\hline 3 & Kerjasama dengan teman & 13 & $61,90 \%$ \\
\hline 4 & Mengajukan pertanyaan pada guru & 10 & $47,61 \%$ \\
\hline 5 & Menjawab pertanyaan guru atau teman & 16 & $76,19 \%$ \\
\hline 6 & $\begin{array}{l}\text { Menulis hasil laporan diskusi dengan } \\
\text { bekerjasama dengan kelompok }\end{array}$ & 14 & $66,67 \%$ \\
\hline \multirow[t]{3}{*}{7} & Melaporkan hasil diskusi & 12 & $57,14 \%$ \\
\hline & Jumlah & 96 & $457,91 \%$ \\
\hline & Rata-rata & $13,71 \%$ & $65,41 \%$ \\
\hline
\end{tabular}

Tabel 4 Presentase Hasil Belajar IPS Siklus 1

\begin{tabular}{llcc}
\hline \multirow{2}{*}{ No } & & \multirow{2}{*}{ Ketuntasan } & \multicolumn{2}{c}{ Jumlah Siswa } \\
& & Jumlah & Presentase \\
\hline 1 & Tuntas & 14 & $67 \%$ \\
2 & Tidak Tuntas & 7 & $33 \%$ \\
& Jumlah & 21 & $100 \%$ \\
\hline
\end{tabular}

Tabel 3 dan tabel 4 menunjukkan presentase keaktifan dan hasil belajar IPS siswa kelas VB SDN 01 Kaliwuluh pada siklus 1. Pada siklus 1 ini dari 7 indikator keaktifan belajar IPS siswa menunjukan bahwa rata-rata keaktifan belajar IPS peserta didik sudah meningkat dari kondisi awal 4,71\% menjadi 13,71\%. Sedangkan hasil belajar IPS pada siklus 1 mengalami peningkatan yaitu pada kondisi awal dari 21 peserta didik dengan KKM 75 hanya ada 8 peserta didik yang tuntas atau memenuhi KKM meningkat menjadi 14 peserta didik yang tuntas atau memenuhi KKM dan 7 peserta didik masih di bawah KKM.

\section{Tabel 5 Presentase Keaktifan Belajar IPS Siklus II}

\begin{tabular}{clcc}
\hline No & \multicolumn{1}{c}{ Indikator } & Jumlah & Presentase \\
\hline 1 & Mencari informasi dan sumber belajar & 18 & $85,71 \%$ \\
2 & Menulis penjelasan guru & 17 & $80,95 \%$ \\
3 & Kerjasama dengan teman & 18 & $85,71 \%$ \\
4 & Mengajukan pertanyaan pada guru & 14 & $66,67 \%$ \\
5 & Menjawab pertanyaan guru atau teman & 18 & $85,71 \%$ \\
6 & Menulis hasil laporan diskusi dengan & 18 & $85,71 \%$ \\
7 & $\begin{array}{l}\text { bekerjasama dengan kelompok } \\
\text { Melaporkan hasil diskusi }\end{array}$ & 14 & $66,67 \%$ \\
\hline
\end{tabular}


SHEs: Conference Series 3 (4) (2020) 528- 535

\begin{tabular}{ccc}
\hline Jumlah & 117 & $557,13 \%$ \\
Rata-rata & $16,71 \%$ & $79,59 \%$ \\
\hline
\end{tabular}

Tabel 6 Presentase Hasil Belajar IPS Siklus 2

\begin{tabular}{llcc}
\hline \multirow{2}{*}{ No } & \multirow{2}{*}{ Ketuntasan } & \multicolumn{2}{c}{ Jumlah Siswa } \\
& & Jumlah & Presentase \\
\hline 1 & Tuntas & 18 & $85,71 \%$ \\
2 & Tidak Tuntas & 3 & $14,29 \%$ \\
& Jumlah & 21 & $100 \%$ \\
\hline
\end{tabular}

Tabel 5 dan tabel 6 menunjukkan presentase keaktifan dan hasil belajar IPS siswa kelas VB SDN 01 Kaliwuluh pada siklus 2. Pada siklus 2 ini terjadi peningkatan lagi dari siklus 1 sebelumnya, dari 7 indikator keaktifan belajar IPS siswa menunjukkan bahwa rata-rata keaktifan belajar IPS peserta didik mencapai $16,71 \%$. Sedangkan hasil belajar IPS pada siklus 2 ini juga meningkat dari siklus 1 yaitu dari 21 peserta didik dengan KKM 75 sudah 18 peserta didik yang tuntas atau memenuhi KKM dan 3 peserta didik masih di bawah KKM.

Tabel 7 Perbandingan Keaktifan Belajar IPS Kondisi Awal, Siklus I dan Siklus II

\begin{tabular}{|c|c|c|c|c|c|c|c|}
\hline \multirow{2}{*}{ No } & \multirow{2}{*}{ Indikator } & \multicolumn{2}{|c|}{ Pratindakan } & \multicolumn{2}{|c|}{ Siklus I } & \multicolumn{2}{|c|}{ Siklus II } \\
\hline & & Jumlah & Presentase & Jumlah & Presentase & Jumlah & Presentase \\
\hline 1 & $\begin{array}{l}\text { Mencari } \\
\text { informasi } \\
\text { dan sumber } \\
\text { belajar }\end{array}$ & 1 & $4,55 \%$ & 15 & $71,42 \%$ & 18 & $86,71 \%$ \\
\hline 2 & $\begin{array}{l}\text { Menulis } \\
\text { penjelasan } \\
\text { guru }\end{array}$ & 10 & $45,45 \%$ & 16 & $76,19 \%$ & 17 & $80,95 \%$ \\
\hline 3 & $\begin{array}{l}\text { Kerjasama } \\
\text { dengan } \\
\text { teman }\end{array}$ & 6 & $27,27 \%$ & 13 & $61,90 \%$ & 18 & $85,71 \%$ \\
\hline 4 & $\begin{array}{l}\text { Mengajukan } \\
\text { pertanyaan } \\
\text { pada guru }\end{array}$ & 2 & $22,72 \%$ & 10 & $47,61 \%$ & 14 & $66,67 \%$ \\
\hline 5 & $\begin{array}{l}\text { Menjawab } \\
\text { pertanyaan } \\
\text { guru atau } \\
\text { teman }\end{array}$ & 6 & $27,27 \%$ & 16 & $76,19 \%$ & 18 & $85,71 \%$ \\
\hline 6 & $\begin{array}{l}\text { Menulis } \\
\text { hasil laporan } \\
\text { diskusi } \\
\text { dengan } \\
\text { bekerjasama } \\
\text { dengan } \\
\text { kelompok }\end{array}$ & 4 & $18,18 \%$ & 14 & $66,67 \%$ & 18 & $85,71 \%$ \\
\hline 7 & $\begin{array}{l}\text { Melaporkan } \\
\text { hasil diskusi }\end{array}$ & 4 & $18,18 \%$ & 12 & $57,14 \%$ & 14 & $66,67 \%$ \\
\hline
\end{tabular}


SHEs: Conference Series 3 (4) (2020) 528- 535

\begin{tabular}{ccccccc}
\hline Jumlah & 33 & $158,62 \%$ & 96 & $457,91 \%$ & 117 & $557,13 \%$ \\
Rata-rata & $4,71 \%$ & $22,66 \%$ & $13,71 \%$ & $65,41 \%$ & $16,71 \%$ & $79,59 \%$
\end{tabular}

Tabel 8 Perbandingan Hasil Belajar IPS Kondisi Awal, Siklus I dan Siklus II

\begin{tabular}{llccc}
\hline No & Keterangan & Pratindakan & Siklus I & Siklus II \\
\hline 1 & Nilai Rata-rata & 64,83 & 76,4 & 83,60 \\
2 & Ketuntasan Klasikal & $33,30 \%$ & $67 \%$ & $85,71 \%$ \\
\hline
\end{tabular}

Berdasarkan tabel 7 dan 8 di atas nilai rata-rata hasil belajar IPS dan presentase ketuntasan minimal mulai dari pratindakan, siklus I, dan siklus II mengalami peningkatan. Pada pratindakan nilai rata-rata hasil belajar IPS sebesar 64,83 meningkat menjadi 76,4 dan pada siklus II meningkat menjadi 83,60 . Sedangkan persentase ketuntasan klasikal pada saat pratindakan hanya $33,30 \%$ pada siklus I meningkat menjadi $67 \%$ dan pada siklus II meningkat menjadi $85,71 \%$.

Berdasarkan hasil penelitian yang dijelaskan di atas, maka dapat disimpulkan bahwa penerapan model pembelajaran kooperatif tipe STAD dapat meningkatkan keaktifan dan hasil belajar IPS pada siswa kelas VB SDN 01 Kaliwuluh semester 1 tahun pelajaran 2020/2021. Dalam penelitian ini, keaktifan dan hasil belajar IPS pada siswa kelas VB telah mengalami peningkatan. Hal tersebut dibuktikan dari adanya perkembangan nilai rata-rata dan ketuntasan klasikal siswa yang dicapai pada saat pratindakan, siklus I, dan siklus II.

Penelitian Tindakan Kelas ini dilatarbelakangi oleh kurangnya keaktifan dan rendahnya hasil belajar IPS. Sehingga peneliti menerapkan model pembelajaran kooperatif tipe STAD pada siswa kelas VB SDN 01 Kaliwuluh semester 1 tahun pelajaran 2020/2021. Pelaksanaan Penelitian Tindakan Kelas ini dilaksanakan dalam dua siklus, dengan tiap siklus terdiri atas perencanaan, pelaksanaan tindakan, observasi, dan refleksi. Subjek penelitian ini adalah siswa kelas VB SDN 01 Kaliwuluh yang berjumlah 21 siswa dengan objek penelitian adalah keaktifan dan hasil belajar siswa. Dari hasil analisis data diketahui bahwa pada setiap siklus terjadi peningkatan keaktifan dan hasil belajar siswa. Pada kondisi awal presentase keaktifan belajar siswa hanya 22,66 \% sedangkan hasil belajar 64,83\% di bawah KKM. Pada siklus I keaktifan belajar meningkat menjadi $65,41 \%$ dan hasil belajar mencapai 76,40 \%. Pada siklus II keaktifan siswa meningkat menjadi 79,59\% dan hasil belajar mencapai $86,60 \%$. Berdasarkan hasil Penelitian Tindakan Kelas dapat disimpulkan bahwa dengan menerapkan model pembelajaran kooperatif tipe STAD dapat meningkatkan keaktifan dan hasil belajar IPS pada siswa kelas VB SDN 01 Kaliwuluh semester 1 tahun pelajaran 2020/2021.

\section{SIMPULAN}

Berdasarkan hasil penelitian yang telah diuraikan, dapat disimpulkan bahwa penerapan model pembelajaran kooperatif tipe STAD dapat meningkatkan keaktifan dan hasil belajar IPS pada siswa kelas VB SDN 01 Kaliwuluh semester 1 tahun pelajaran 2020/2021. Hal tersebut dibuktikan dari adanya peningkatan nilai rata-rata kelas dan ketuntasan klasikal siswa yang dicapai pada setiap siklusnya dengan nilai KKM 75. Pada pratindakan keaktifan siswa hanya $22,66 \%$, meningkat menjadi $65,41 \%$ 
dan meningkat menjadi $79,59 \%$. Sedangkan nilai rata-rata hasil belajar IPS dan presentase ketuntasan minimal mulai dari pratindakan, siklus I, dan siklus II mengalami peningkatan. Pada pratindakan nilai rata-rata hasil belajar IPS sebesar 64,83 meningkat menjadi 76,4 dan pada siklus II meningkat menjadi 83,60 . Sedangkan prsentase ketuntasan klasikal pada saat pratindakan hanya $33,30 \%$ pada siklus I meningkat menjadi $67 \%$ dan pada siklus II meningkat menjadi $85,71 \%$.

Berdasarkan kajian teori, hasil penelitian, dan simpulan terbukti bahwa penerapan model pembelajaran kooperatif tipe STAD dapat meningkatkan keaktifan dan hasil belajar IPS pada siswa kelas VB SDN 01 Kaliwuluh semester 1 tahun pelajaran 2020/2021. Dengan demikian, implikasi penelitian tindakan kelas ini adalah:

1. Implikasi Teoritis

Hasil penelitian menunjukkan bahwa penerapan model pembelajaran kooperatif tipe STAD dapat meningkatkan keaktifan dan hasil belajar IPS pada siswa kelas VB SDN 01 Kaliwuluh semester 1 tahun pelajaran 2020/2021. Hal ini menunjukkan bahwa secara teoritis hasil penelitian ini dapat digunakan sebagai salah satu acuan untuk menerapkan model pembelajaran kooperatif tipe STAD dalam pembelajaran IPS pada materi yang sesuai untuk meningkatkan penguasaan konsep siswa. Hasil penelitian ini juga dapat memperluas wawasan dan pengetahuan bagi pembaca mengenai pentingnya model pembelajaran yang bervariasi untuk meningkatkan penguasaan konsep siswa dalam pembelajaran IPS.

2. Implikasi Praktis

Hasil penelitian ini secara praktis dapat diterapkan pada pembelajaran IPS di SDN 01 Kaliwuluh, yaitu dengan menerapkan model pembelajaran kooperatif tipe STAD untuk meningkatkan keaktifan dan hasil belajar dalam pembelajaran.

\section{DAFTAR PUSTAKA}

Agus Suprijono. 2012.Cooperative Learning. Yogyakarta: Pustaka Belajar.

Ahmad Rohani. 2010. Pengelolaan Pengajaran. Jakarta: Rineka Cipta.

Anas Sudjono. 2009 Pengantar Statistik Pendidikan. Jakarta: Grafindo.

Bahris Salim dan Abdul Haris. 2011. Modul Strategi Dan Model-Model PAIKEM. Direktorat Pendidikan Agama Islam: Direktorat Agama Republik Indonesia.

Isjoni \& Mohd. Arif Ismail. 2008. Model-Model Pembelajaran Mutakhir. Yogyakarta: Pustaka Belajar

Isjoni. 2010. Cooperative Learning Efektifitas Pembelajaran Kelompok. Bandung: Alfabeta

Rusman. 2012. Model-Model Pembelajaran Mengembangkan Profesionalisme Guru (ed. 2). Jakarta : PT Raja Grafindo Persada

Sumardi, Kasmin. 2011. Penelitian Tindakan Kelas.

Sudjana, N. 2010. Cara Belajar Siswa Aktif Dalam Proses Belajar Mengajar. Bandung: Sinar Baru Algensindo

Suharsimi Arikunto. 2012. Penelitian Tindakan Kelas. Jakarta: Bumi Aksara. 